Available online on 15.05.2020 at http://jddtonline.info
Open Access to Pharmaceutical and Medical Research
undestricted non-commercial use, provided the original work is properly cited

Open 1 Access

Review Article

\title{
Biological Potential of Tribulus terrestris
}

\author{
Shantanu U. Dighe*, R.S. Jadhav, D.N. Vikhe
}

Department of Pharmacognosy, Pravara Rural College of Pharmacy, Pravaranagar, A/P. Loni BK. Tal. Rahata, Dist. A. Nagar, (Maharashtra) India

\begin{abstract}
Plants have a significant role in preserving human health and improving quality of life. gokshura (Tribulus terrestris Linn.) one of such plants, is mentioned in Ayurvedic texts for various therapeutic properties like balya(strengthening), brimhana (nutritive), rasayana(rejuvenator), mootrala(diuretic), shothahara(anti-inflammatory), vajikarana (aphrodisiac) etc. and useful in the management of mutrakrichhra (dysurea), ashmari (renal calculi) etc. It is a perennial plant, grown predominantly in India and Africa. Its extract contains alkaloids, saponins, resins, flavanoids and nitrates. As its therapeutic values, a review has been done to gather information on different aspects of gokshura. Further Ayurvedic references, the present paper also emphasizes on recent researches carried out on this plant for its pharmacological evaluation.
\end{abstract}

Keywords: Tribulus terrestris, Diuretic, Pharmacology

Article Info: Received 22 Feb 2020; Review Completed 19 April 2020; Accepted 27 April 2020; Available online 15 May 2020

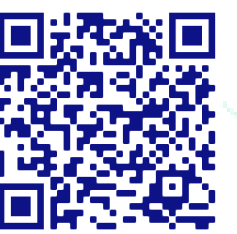

Cite this article as:

Dighe SU, Jadhav RS, Vikhe DN, Biological Potential of Tribulus terrestris, Journal of Drug Delivery and Therapeutics. 2020; $10(3): 262-264 \mathrm{http} / / / d x . d o i . o r g / 10.22270 / j d d t . v 10 i 3.3982$

\section{*Address for Correspondence:}

Shantanu U. Dighe, Department of Pharmacognosy, Pravara Rural College of Pharmacy, Pravaranagar, A/P. Loni BK. Tal. Rahata, Dist. A. Nagar, (Maharashtra) India

\section{Introduction:}

Tribulus terrestris (gokshura) is a procumbent annual herb and belongs to Zygophyllaceae family. ${ }^{1}$ It is native to southern Europe, Africa, temperate and tropical Asia. ${ }^{2}$ Tribulus terrestris is developed to warm, moderate regions and is predominant in areas having hot summers and dry soils. In India, Tribulus terrestris is found primarily on loose and compact sandy loam soils, and reportedly grows on sand hills in the desert regions. ${ }^{3}$

\section{Pharmacological Activity:}

\section{Aphrodisiac activity:}

Gokshura is highlighted to be a vajikara dravya (aphrodisiac). ${ }^{4}$ Studies reported that, furastanolic type of saponin present in T. terrestris increases the amount of luteinizing hormone (LH), motivate spermatogenesis and results in motivation of Testosterone. These activities may help in civilizing the quality and quantity of sperm significantly. ${ }^{5}$ Furostanol saponin extract from $T$. terrestris shows positive effect on spermatogenesis of rams during breeding season with increase in count of spermatozoids, time of viability and sperm motility. ${ }^{6}$

\section{Diuretic activity:}

The plant is found to be helpful in diuresis. Potassium and rich amount of nitrates present in the plant may be responsible for this activity. ${ }^{7}$

\section{Urolithiatic activity:}

Ethanolic extract of the fruits of Tribulus terrestris displayed significant dose dependent protection against uroliths induced by glass bead implantation in albino rats. ${ }^{8}$

\section{Effect on hypertension:}

Decreased systolic blood pressure was reported with the treatment of lyophilized aqueous extractof tribulus fruits. ${ }^{9}$ gokshura ghana (solid aqueous extract) is reported to be used in mild to temperate essential hypertension. ${ }^{10}$

\section{Anti-hyperlipidemic effect:}

Methanolic extract of Tribulus terrestris show hypolipidemic effect.11 Saponins of Tribulus terrestris were found to significantly lower serum total cholesterol, low density lipoprotein cholesterol and liver total cholesterol, triglycerides in diet-induced hyperlipidemia in mice. ${ }^{12}$

\section{Effect on diabetes mellitus:}

Levels of malondialdehyde (MDA) and significant recovery of liver was found in treated rats. ${ }^{13} T$. terrestris methanolic extract caused a significant decrease in blood glucose level and glycosylated haemoglobin. ${ }^{12}$ In another study, methanolic extract of T.terrestris showed significant decrease in blood sugar level. ${ }^{7}$ 


\section{Cardio-protective effect:}

Hydro-alcoholic lyophilized extract of whole plant of Tribulus terrestris has been reported to have cardioprotective function. The fraction is reported to attenuate myocardial infarction in rats. ${ }^{14}$

\section{Analgesic effect:}

Methanolic extract of fruits reported to have analgesic activity. The extract also found to have smaller gastric ulcerogenic activity as compared to Indomethacin. ${ }^{15}$

\section{Antispasmodic activity:}

Significant decrease was found in peristaltic movement of sheep ureter and rabbit jejunum when treated with liopihilized saponin extract of dried and powered Tribulus terrestris. 16

\section{Anti-microbial activity:}

Spirosponin, ethnolic extract of the fruit and leaves of Tribulus terrestris has activity against E. coli and S. aurue. ${ }^{17}$ Hexanoic and methanolic extracts of the plant showed significant activity against bacteria like E. coli,Pseudomonas aeruginosa, Klebsiella pneumoniae, Proteus vulgaris and Staphylococcus aureus. ${ }^{6}$ Tribulosin andsitosterol glycosides present in 50\% methanolic extract of T.terrestris reported to possess anti-helminthic properties. ${ }^{17}$ Steroidal saponins from T.terrestris Linn. have antifungal action again stfluconazole-resistant fungi (Candida albicans,Candida glabrata, Candida parapsilosis,Candida tropicalis, Candida krusei, andCryptococcus neoformans). ${ }^{18}$

\section{Cytotoxic effect:}

T.terrestris of different regions (Bulgaria, Chinaand India) and different parts of plants (stem and fruit) shows that only the spiro compounds exhibit remarkable activity. The inhibitory effect of saponin mixture from Chinese origin on Bcap37 breast cancer cell has potent inhibitory effect. ${ }^{19}$ In another study, data showed that Tribulus terrestris aqueous extract blocks proliferation and induces apoptosis in human liver cancer cells through the inhibition of NF_B signalling and can be used as an anticancer drug for hepato cellular carcinoma patients. ${ }^{20}$ Total extract of the Bulgarian T.terrestris has a marked dose-dependent inhibitory effect on viability of breast cancer cells whereas saponin fraction has increased inhibitory effect compared to the total extract. Morphologicalchanges and DNA fragmentation were observed as markers for early and late apoptosis in tumor cells after treatment. In the mechanisms of antitumor activity of T.terrestris apoptotic processes are involved. Apoptotic processes showed selective antitumor activity of Bulgarian Tribulus terrestris Linn. on human cancer cells in vitro. $^{21}$

\section{Wound healing action:}

The leaves of Tribulus terrestris are used traditionally in folklore for the treatment of various kinds of wounds. Aqueous extract in carbopol at $2.5 \%$ and $5 \%$ concentrations showed significant reduction in period of epithelisation and wound contraction by $50 \%$ in excision and burn wound models. In the incision wound model a significant increase in the breaking strength was observed. ${ }^{22}$

\section{Nutritional values:}

Tribulus terrestris is found to be rich source of calcium..$^{23}$

\section{Contraindications:}

Use of drug is contraindicated in dehydration ${ }^{24}$ and pregnancy. 25

\section{References:}

1 Sharma PC, Yelne MB, Dennis TJ. Database on Medicinal plants used in Ayurveda and Sidha. New Delhi: CCRAS, Dept. of AYUSH, Ministry of Health and Family Welfare, Govt. of India; vol 3. 2000. p.229.

2 Parker KF. An Illustrated Guide to Arizona Weeds. Tucson (AZ):The University of Arizona Press. 1972, p.338.

3 Pathak, PS. Contributions to the ecology of Tribulus terrestris Linn. II. Habitat studies, Agra University Journal of Research Science 1970; 19(2):149-166.

4 Dhanwantari. Dhanvantari Nighantu. Sharma PV, Sharma GP. editor, reprint edition. Varanasi: Chaukhambha Orientalia, 2008, p. 34 .

5. Abbas A. Al-Amiery MAAH, Al-Mosowy AAH, Abbas AH. Study the biological activities of Tribulus terrestris extracts. Journal of Biotechnology Research Center 2010; 4(1):55-60.

6. Kistanova E, Zlatev H, Karcheva V, Kolev A.Effect of plant Tribulus terrestris extract on reproductive performances of rams. Biotechnology in Animal Husbandry, 2005; 21(1-2):55-63.

7. Ukani MD, Nanavati DD, Mehta NK. A Review on the Ayurvedic herb Tribulus terrestris L. Ancient Science of Life 1997; 17(2):144-150. PubMed PMID: 22556836.

8. Anand R, Patnaik GK, Kulshreshtha DK. Dhawan BN, Activity of certain fractions of Tribulus terrestris fruits against experimentally induced urolithiasis in rats, Indian journal of experimental biology. Indian J Exp Biol 1994; 32(8):548-552. PubMed PMID: 7959935.

9. Sharifi AM. Radbod Darabi, Nasrin Akbarloo, Study of antihypertensive mechanism of Tribulus terrestris in $2 \mathrm{~K} 1 \mathrm{C}$ hypertensive rats. Role of tissue ACE activity, Life sciences 2003; 73(2003):2963-297. PubMed PMID: 14519445.

10. Murthy AR, Dubey SD, Tripathi K. Anti-hypertensive effect of Gokshura (Tribulus terrestris Linn.) A clinical study, Ancient Science of Life 2000; XIX(3-4):139-145.

11. EI-Tantawy WH, Hassanin LA. Hypoglycemic and hypolipidemic effects of alcoholic extracts of Tribulus alatus in streptozotocininduced diabetic rats: A comparative study with T. terrestris, Indian journal of experimental biology 2007; 45:785-90.

12. Shudi C, Weijing Q, Xiufeng P, Bin S. Huang Xiaoqing, Effect of Saponin from Tribulus terrestris on Hyperlipidemia. Journal of Chinese Medicinal Material 2003; 26(5):2003-5. PubMed PMID: 14535016.

13. Amin AMR. Mohamed Lotfy, Mohamed Shafiullah, Ernest Adeghate, The Protective Effect of Tribulus terrestris in Diabetes. Annals of the New York Academy of Sciences 2006; 1084(2006):391-40. PubMed PMID: 17151317. doi: 10.1196/annals.1372.005.

14. Ojha SK, Nandave M, Arora S, Narang N, Dinda AK, Arya DS. Chronic Administration of Tribulus terrestris Linn. extracts improves cardiac function and Attenuates Myocardial Infarction in Rats, International Journal of Pharmacology 2008; 4(1):1-10.

15. Heidari MR, Mehrabani M, Pardakhty A, Khazaeli P, Zahedi MJ, Yakhchali M, et al. The Analgesic Effect of Tribulus terrestris Extract and Comparison of Gastric Ulcerogenicity of the Extract with Indomethacine in Animal Experiments. Annals of the New York Academy of Sciences 2007; 1095(2007):418-427. PubMed PMID: 17404054. doi: 10.1196/annals.1397.045.

16. Arcasoy HB, Erenmemisoglu A, Tekol Y, Kurucu S, Kartal M. Effect of Tribulus terrestris L. saponin mixture on some smooth muscle preparations: a preliminary study.. Boll Chim Farm 1998; 137(11):473-5. PubMed PMID: 10077881.

17.Joshi DD, Uniyal RC. Different chemo types of Gokhru ( Tribulus terrestris ): A herb used for improving physique and physical performance. Int J Green Pharm 2008; 2:158-61.

18. Zhang Jd. Yong bing Cao, Zheng Xu, Hui Hua Sun, In Vitro and in Vivo Antifungal Activities of the Eight Steroid Saponins from 
Tribulus terrestris L. with Potent Activity against FluconazoleResistant Fungal. Biol. Pharm. Bull 2005; 28(12):2211-5. PubMed PMID: 16327151.

19. Sun $B, Q u$ W, Bai Z. The inhibitory effect of saponins from Tribulus terrestris on Bcap-37 breast cancer cell line in vitro. Zhong Yao Cai 2003; 26(2):104-106. PubMed PMID: 12795220.

20. Kim HJ, Kim JC, Min JS, Kim MJ, Kim JA, Kor MH, et. al. Aqueous extract of Tribulus terrestris Linn. induces cell growth arrest and apoptosis by down-regulating NF_B signaling in liver cancer cells, Journal of Ethnopharmacology, 2011;136(1):197-203. doi: 10.1016/j.jep.2011.04.060.

21. Angelova S, Gospodinova Z, Krasteva M, Antov G, Lozanov V, Markov T, et. al. Antitumor activity of Bulgarian herb Tribulus terrestris L. on human breast cancer cells, J BioSci Biotech 2013; 2(1):25-32.

22. Wesley JJ, Christina AJM, Chidambaranathan N, Ravikumar K. Wound healing activity of the leaves of Tribulus terrestris (Linn.) aqueous extract in rats, Journal of Pharmacy Research 2009; 2(5):841-3.

23. Duhan A, Chauhan BM, Punia D. Nutritional value of some nonconventional plant foods of India. Plant Foods Hum Nutr. Jul 1992; 42(3):193-200.

24. Frawley D, Lad V. The Yoga Of Herbs: An Ayurvedic Guide to Herbal Medicine. Santa Fe:Lotus Press; 1986. p.169.

25. Bensky D, Gamble A. Chinese Herbal Medicine Materia Medica. revised editionSeattle: Eastland Press;1993. p.42. 